УДК 321.7

\title{
ПОЛІТИЧНА КОМУНІКАЦІЯ В МЕРЕЖІ ІНТЕРНЕТ ЯК НОВИЙ ВЕКТОР РОЗВИТКУ ПОЛІТИЧНОЇ КУЛЬТУРИ В КРАЇНАХ АРАБСЬКОГО СВІТУ
}

\section{Вербицька Ганна Анатоліївна}

асистент,

Київський національний університет культури і мистецтв, м. Київ, Украӥна, ORCID: 0000-0003-4009-5481

annaonline5@gmail.com

У статті, в контексті аналізу трансформації ролі Інтернету, починаючи з початку 90-х pp.XX ст. і до нашого часу як фактору швидкого поширення інформаційних технологій та зростання кількості користувачів мереж (із декількох мільйонів до декількох мільярдів) не тільки для розваг, спілкування чи пошуку інформації, концептуалізується його значення як впливового політичного інструменту у боротьбі за владу. Стверджується, що Інтернет в останні десятиліття почав набувати ролі могутнього й інформаційного двигуна, що розвивається за рахунок соціальних мереж. Саме соціальні мережі стали ареною як внутрішньої, так і міжнародної політичної боротьби.

Висловлюється теза про те, що специфіка геокультурного чинника «століття нових технологій» особливо показово проявилася в період «арабської весни». При цьому в країнах арабського світу свобода Інтернету не скрізь однакова. В країнах Перської затоки вона обмежена. Фактор соціальних мереж в протестних рухах потребує більш детального дослідження, особливо це стосується рівня політичної культури, економічного розвитку та суспільної свідомості населення арабських країн.

Ключові слова: Інтернет; Арабська весна; еліта; трансформація; соціальні комунікації; політична культура; політична система.

Verbytska Hanna, Assistant, Kyiv National University of Culture and Arts, Kyiv, Ukraine

Political communication in the internet network as a new vector for the political culture development in the Arab world countries

Since early 90's of the XX century up to our times, in the context of the Internet role transformation analysis, it has become a factor of the information technology rapid spread and the number of network users growth (from several 
millions to several billion) not only for entertainment, communication or search information, but also it has acquired significance as an influential political tool in the struggle for power, thus conceptualizing the relevance of the current study. For the last decades, the Internet has begun gaining the role of a powerful and informative engine, developing at the expense of social networks. It is social networks that have become an arena for both domestic and international political struggle.

The study suggests a thesis that the geo-cultural factor specificity of the "century of new technologies" was significantly evident during the "Arab Spring" period. Herewith, the freedom of the Internet is not the same in the Arab world countries. It is rather limited as taken for the Gulf countries. The factor of social networks in protest movements requires a more detailed study, especially in relation to the level of political culture, economic development and public consciousness of the Arab countries population.

Key words: Internet; Arab Spring; elite; transformation; social communications; political culture; political system.

Вербицкая Анна Анатольевна, ассистент, Киевский национальный университет культуры и искусств, г. Киев, Украина

\section{Политическая коммуникация в сети Интернет как новый вектор развития политической культуры в странах арабского мира}

В статье, в контексте анализа трансформации роли Интернета, начиная с 90-х гг. XX в. и до нашего времени как фактора быстрого распространения информационных технологий и рост числа пользователей сетей (с нескольких миллионов до нескольких миллиардов) не только для развлечений, общения или поиска информации, концептуализируется его значение как влиятельного политического инструмента в борьбе за власть. Утверждается, что Интернет в последние десятилетия начал приобретать роли могущественного и информационного двигателя, развивается за счет социальных сетей. Именно социальные сети стали ареной как внутренней, так и международной политической борьбы.

Выдвигается тезис о том, что специфика геокультурного фактора «век новых технологий» особенно показательно проявилась в период «арабской весны». При этом в странах арабского мира свобода Интернета не везде одинакова. В странах Персидского залива она ограничена. Фактор социальных сетей в протестных движениях требует более детального исследования, особенно по отношению к уровню политической культуры, экономического развития и общественного сознания населения арабских стран.

Ключевые слова: Интернет; Арабская весна; элита; трансформация; социальные коммуникации; политическая культура; политическая система. 


\section{Вступ}

Насамперед, необхідно зауважити, що правлячі еліти держав Перської затоки, Півночі Африки не уникли впливу нових комунікативних технологій та наслідків їх використання в політичній боротьбі. У тих країнах, де «арабська весна» була спровокована користувачами Інтернет започатковано зміни в політичній культурі і очікуються трансформація політичної системи. Теоретична рефлексія цього процесу $\epsilon$ актуальною й необхідною для узагальненого трактування можливих політичних сценаріїв в «цифрову» епоху. Тут ми цілком погоджуємося із твердженням дослідника П. Hорріс (P. Norris) про те, що нині арабська еліта перебуває під значним глобальним тиском в контексті прийняття цифрової трансформації в суспільстві як для стимулювання своїх економік, так і для отримання іноземної допомоги та аналітиків Алі Ф.Емдад (Ali F. Emdad), Мухаммед Бадамас (Muhammed Badamas), Самар Моуаккет (Samar Mouakket) про необхідність розуміння того, як і чому Інтернет широко використовується в арабських країнах і $\epsilon$ важливим для дослідників і політиків.

\section{Аналіз останніх досліджень та публікацій}

Аналіз наукового дискурсу підтверджує наші тези: 1) про те, що Інтернет призвів до усвідомлення прогалин у технологіях між розвинутими країнами та країнами, що розвиваються та наслідки цифрового розриву; 2) про наслідки використання і поширення Інтернету в світ (економічні, культурні та політичні наслідки Інтернету в історичному контексті країн, що розвиваються; 3) характеристики Інтернету та електронної комерції в арабських країнах та найважливіші завдання, що стоять перед поширенням Інтернет та його застосування відомих політиків у цих країнах.

Автор визнає пріоритет розгляду комунікацій у широкому контексті суспільних трансформацій та парадигм таких дослідників, зокрема: «інформаційне суспільство» (М. Кастельс), «постіндустріальне суспільство» (Д.Белл, А. Турен), «постмодерне суспільство» (Ф. Ліотар, Ж. Бодріяр, Ф. Джеймісон, Ж. Дельоз, 3. Бауман та ін.), «суспільство послуг» (Д. Рісман, А. Етціоні), «мозаїчна культура» (А. Моль), «суспільство знань» (П. Друкер, Ф. Вебстер, Х.-Д. Кюблер), «самореферентні системи» (Н. Луман, У. Матурано), «суспільство ризику» (У.Бек), «пізній модерн» (Е. Гіденс, Ю. Г'абермас), «комунікативне суспільство» (Р. Мюнх, К. Мертен).

Специфіку теоретичних підходів до дослідження політичних комунікацій та визначено роль у розумінні їх сутності таких теорій, як інституціоналізм та неоінституціоналізм (М. Вебер, Р. Патнем, Дж. Сарторі, Дж. Марч, П. Олсен та ін.), біхевіоралізм (Г. Ласуел, П. Лазарсфельд, Р. Даль, Д. Істон та ін.), функціоналізм та неофункціоналізм (Р. Мертон, Л. Козер, Н. Луман, Дж. Александер та ін.), теорію еліт (Ч. Мілз, Й. Шумпетер, Т. Боттомор 
та ін.), теорію мережевого плюралізму (Дж. Річардсон, Б. Веллман, Т. Бьорцель, К. Даудінг, Л. Пал), теорію політичної культури (Г. Мак-Люен, А. Моль, С. Холл та ін.), теорію встановлення порядку денного (М. Мак-Комбс, Д. Шоу та ін.).

При звернені до проблем еволюції комунікативних мереж особливо корисними для нашого дослідження виявилися праці таких зарубіжних та вітчизняних дослідників, як Б. Андерсон, 3. Бауман, В.Бебик, Ж. Бодріяр, П. Бурдьє, Г. Вайнштейн, О. Вартанова, Б. Дубін, Б. Дьякова, I. Засурський, Л. Землянова, О. Зернецька, М. Кастельс, Н. Костенко, Х.-Д. Кюблер, Дж. Лалл, г. Ласуел, Н. Луман, М. Мак-Комбс, М. Маклюен, В. Недбай, І. Нєнов, Г. Оберройтер, Дж. Пітере, М. Польовий, Б. Потятиник, Г. Почепцов, А Сіленко, О. Соловйов, О. Тоффлер, Д. Яковлев та ін.

Загальні роботи з політичних наук, у яких висвітлюється проблема визначення сутності мережі Інтернет та особливостей Інтернет-комунікацій, належать таким зарубіжним та вітчизняним авторам, як С. Алстром, В. Бебик, В. Білоус, К. Боулдінг, Н. Вінер, А. Гальчинський, Е. Гелнер, К. Гірц, М. Головатий, Г. Грачов, П. Друкер, О. Дубае, М. Кастельс, В. Коляденко, В. Королько, Л. Кормич, Л. Кочубей, Ю. Левенець, Г. Маклюен, Р. Макрідіс, Г. Почепцов, Д. Рісмен, О. Соснін, Т. Фрідмен, Ф. Фукуяма, Д. Яковлев та ін.

\section{Формулювання цілей статті}

Після вибуху Арабської весни в середовищі наукової спільноті постала проблема вивчення не лише рушійних сил цього явища, але й впливу на його розвиток соціальних мереж, зокрема Інтернету. Тому однією із цілей даної роботи $є$ з'ясування їх ролі у протестних рухах арабського світу.

\section{Виклад основного матеріалу}

У наш час термін «політична культура» став одним з найбільш уживаних як серед політиків, так і серед науковців. У дослідженнях науковців О. Кваші «Політична культура в контексті регіональної політики», В. Культенко «Культурна політика та політична культура: кореляція понять та феноменів» політична культура визначається як система феноменів суспільної свідомості, а в більш широкому розумінні - як загальна національна культура, яка впливає на функціонування та розвиток державних і політичних інститутів і надає значимість і напрям політичним процесам, і політичному життю загалом. Західні вчені М. Доган та Д. Пелассі зазначають, що саме культура визначає позиції людей і відчутно впливає на форми політичної активності; вона $\epsilon$ сутнісним елементом політичного життя народу. Саме тому ми повинні схвалювати дослідження, які мають на меті зрозуміти, чим визначається суть політичної культури, від чого вона залежить, як, разом з якими процесами, під впливом яких конфліктів, подій вона формується (Dogan, 1994, p. 98-105). Термін «політична культура» в українській політичній літературі вперше вжив В.Липинський. Уйого розумінні сутність політичної культури полягає 
в поєднанні, у «рівновазі» між «політичною творчістю» й «політичною наукою», що забезпечує високу «політичну вмілість» провідної верстви нації та всього народу. За В.Липинським, «пристосування до політичної творчості даних політичної науки виходить у сферу політичної умілості. Така чи інша рівновага між першою і другою - таке чи інше уміння використовувати для творчості дані науки - лежить в основі того, що прийнято звати політичною культурою» (Lypynskyi, 1995, p. 74). Можна зауважити, що політична культура та політична поведінка громадянина - це дві підсистеми, які впливають одна на одну та не можуть існувати одна без одної. Як зазначає В. Горбатенко, дієву модель політичної системи неможливо створити лише через політику, інструментальними засобами. Ї̈̈ можна творити через культуру, через залучення потенціалу базових цінностей. Важливо, щоб в процесі транзиту від тоталітаризму до демократії змінювалась політична поведінка громадян, їх політична культура. В умовах модернізації політичної системи суспільства зростає роль і значення політичної соціалізації, результатом якої і повинна стати «нова політична культура». Для їі формування важлива не тільки інституційна трансформація, а й створення іншої системи культурних цінностей, тобто трансформація культури діяльності політичних інститутів. У більшості країн постсоціалістичного простору йде переважання на інституціональному рівні політичної культури радянського типу, що спричиняє гальмівний вплив на темпи суспільних перетворень. Це пов'язане, насамперед, 3 незмінністю політичної еліти. Перехід до демократичного політичного режиму відбувався шляхом входження старих еліт, що виховані на канонах ієрархічної підпорядкованості, у нові структури та відносини. Нездатність і небажання цих еліт поставити інтереси суспільства вище власних інтересів і амбіцій $є$ головною перешкодою на шляху становлення демократії.

Значний внесок в розробку близькосхідної і арабської тематики внесли О. Борисов, О. Васильєв, А. Єгорін, В.Кисельов, Р. Ланда, Л. Медведко, Г. Мирський, Є. Примаков, І. Беляев, В. Нагайчук, Є. Пирлін, М. Сапронова. Серед провідних центрів дослідження політичних систем та проблем політичного розвитку арабських держав в Україні варто зазначити Інститут міжнародних відносин Київського національного університету імені Тараса Шевченка, відділ Азії та Африки Інституту світової економіки та міжнародних відносин Національної академії наук України, Інститут сходознавства ім. А. Ю. Кримського Національної академії наук України. Значний внесок у дослідження розвитку політичних та соціальних процесів арабських держав зробили такі українські дослідники, як О. Коппель, Ю. Скороход, О. Пархомчук, В. Гура, Ю. Кочубей, Б. Парахонський, О. Волович, А. Веселовський. Ці науковці стверджують, що загальна арабська культура теж поняття сумнівне. Досить подивитися на чоловічі хороводи бедуїнів Аравії і швидкі танці ліванців 
або танець живота. Навіть у національній кухні немає нічого спільного між магрибським кускусом і іракським мазкуфом. Поняття «араби» скоріше близьке поняттю «європейці», або, принаймні, має такий же зміст, як слов'яни, германці, романські народи або латиноамериканці. Навіть етнічно 100 відсотків араби залишилися хіба, що в деяких частинах Аравії (Неджді і в Катарі). Решта змішалася з місцевим населенням під час арабських завоювань VII-VIII ст., або з сусідніми турками, персами, курдами, неграми, кавказцями, європейцями, туарегами та ін. Узагальнюючи, араби - це певна спільнота семітських за походженням народів, що мають спільну літературну мову, засновану на Корані, приблизно однакову історичну долю (частина Османської імперії, потім протекторати Англії та Франції) і відносно схожі культури і традиції пустельних народів Аравії та Сахари. Хоча й це визначення не точне. Зазначимо, що міжарабські протиріччя - це протиріччя між різними арабськими країнами і регіонами.

Отже, сьогодні більшість арабських країн переживають перехідний етап розвитку. Після повалення диктаторських режимів внаслідок «арабської весни» в більшості республік до влади прийшли помірні ісламісти, котрі ще п’ять років, тому були поза законом і не могли претендувати на першість. У монархіях клерикальні сили виступають гальмом суспільного розвитку нав'язуючи усталені стереотипи суверенам. Винятком може слугувати лише Марокко, де вуличні протести, підбурені ісламістами призвели до політичних реформи «згори». Складність ситуації полягає в зростанні впливу ісламських радикальних рухів, що в умовах конституційного процесу вимагають від своїх більш помірних колег, що знаходяться у владі, прийняття нових конституцій, що за своє сутністю ставлять під сумнів світськість державної влади та можуть призвести до трансформації балансу сил в арабському та ісламському світах.

Дослідник М. Кирюшко пов'язує політичний іслам 3 появою «специфічних політичних форм ісламської практики» і вкладає в це поняття подвійний зміст: «1) рух мусульман за набуття державної влади 3 метою використання держави як знаряддя, засобу або першого кроку до глобального утвердження ісламу у регіоні або в світі в цілому; 2) окрема ідеологія або сукупність ідеологій, спільним витоком яких $\epsilon$ уявлення про принципову неподільність політики та релігії ісламу, а природним наслідком - діяльність із створення ісламських держав як бази для поширення й утвердження ісламу у світі» (Kyriushko, 2010, р. 46).

Нові дослідження потребують нових фактів. Зокрема, у самому зародженні соціальних мереж головним фактором їх реалізації була комунікативна функція, що передбачала комп'ютеризоване спілкування між людьми за допомогою Інтернету. Однак, XXI ст. вже було ознаменовано «Століттям нових технологій». 
За таких обставин, Інтернет 3 його первинною функцією «Пошук», отримав роль могутнього комунікаційного й інформаційного двигуна, що стрімко розвивається саме за рахунок соціальних мереж (Panjusheva, 2011, p. 8).

Вже зараз можемо спостерігати, що соціальні мережі стали ареною політичної боротьби - як внутрішньої, так і міжнародної. Дедалі частіше вони використовуються не тільки як інформаційний майданчик, а як координатор тих чи інших масових дій. 3 розвитком телекомунікацій, суспільство отримало доступ до величезного масиву інформації, до можливості висловлювати свої думки і робити колективні дії. Загальновідомий факт, що соціальні медіа стали невід'ємною частиною громадянського суспільства у всьому світі. Соціальні мережі стають центром обміну думками, актуальною або фундаментальною інформацією (Baluev, 2012, р. 4).

Особливо варто звернути увагу на такі нові явища в Інтернет середовищі, зокрема у глобальних соціальних мережах, як Віртуальна солідарність людей (ВСЛ), котрі знаходяться в мережі. Вищезгадане явище особливо гостро проявило себе під час Арабських революцій у 2011 р., в таких країнах як Єгипет, Лівія, Сирія, коли абсолютно незнайомі люди у величезній кількості за допомогою соціальних мереж об'єднувалися через Інтернет, планували й організовували спільні політичні акції протесту. Таким чином, соціальні мережі сприяли дуже швидкому об'єднанню людей із єдиною і конкретною метою, у даному випадку - організація акцій протесту проти чинної влади.

Важливо відзначити, що Інтернет $є$ в усіх арабських країнах, навіть в Сомалі, де в 2016 р. їм користувалося лише 2 \% населення. Однак розвиток Інтернету, як зазначалося вище, неоднаковий, що в певній мірі пояснюється неоднорідною економічною ситуацією в регіоні. Якщо в Катарі, країніекспортері природного газу, практично кожен житель користується послугами Інтернету, то в Єгипті кількість користувачів становить 40 \% населення країни.

Неоднорідність спостерігається і в цензурі. Соціальні мережі обмежені у всіх країнах Перської затоки (за винятком Кувейту), Ємені, Судані, Марокко і Тунісі. Найбільш м'яке законодавство діє в Лівані, Єгипеті та Іраку, де обмежені лише торрент-трекери.

У цілому, ситуація з поширеністю і свободою Інтернету в арабських країнах не ідеальна, але спостерігаються і масштабні позитивні зрушення. Наприклад, такі країни як Бахрейн (50-е місце), Марокко (54-е місце), Катар (51-е місце) і Саудівська Аравія (69-е місце) за п'ять років на третину поліпшили доступ і поширеність до інтернет-ресурси. Велику роль у цьому зіграло і повсюдне поширення телефонів з функцією доступу в Інтернет. Однак, серед країн що розвиваються, лише Марокко вдалося забезпечити доступом до 
Інтернету 50 \% населення країни. Примітно, що жінки набагато більш активно, ніж чоловіки використовують можливості, надані мережею Інтернет. Так, наприклад, тільки одна з п'яти жінок в Єгипті (63-е місце) вважає, що Інтернет-спілкування - це не важливий вид комунікації. У той же час, такий же відсоток жіночого населення переконаний, що право на доступ до Інтернету $є$ одним $з$ фундаментальних прав людини. Одним 3 пріоритетних напрямків інформаційної політики сучасних держав залишається забезпечення доступу до Інтернету (зокрема, до сайтів державних органів і соціальних служб) для осіб з обмеженими фізичними можливостями, однак, лише 16 країн 381 беруть участь в рейтингу, забезпечують це право на законодавчому рівні. Серед них Катар, де інтеграція інвалідів у соціальний простір за допомогою мережі Інтернет $є$ одним з пріоритетних напрямків роботи катарського уряду. У той же час, Близький Схід, Азія і Африка залишаються країнами, де доступ до інформації про державний бюджет країни залишається найбільш закритим. Місцеві уряди прагнуть обмежити кількість ресурсів і інформації, які були б доступні в Мережі і відображали процес формування бюджету. Природно, що про участь населення, хоча б на рівні суспільної дискусії, в формуванні бюджетних статей не йдеться.

Після подій «Арабської Весни», адміністрація Барака Обами актуалізувала Інтернет і соціальні мережі як ефективний інструмент для певних змін. У рамках реалізації нового політичного курсу, мільйони доларів були витрачені на те, щоб навчити активістів-мусульман, як використовувати Інтернет у своїх цілях. «Ми хочемо, щоб Інтернет залишався доступним для протестуючих, які за допомогою соціальних мереж організовують демонстрації в Єгипті, для студентів, які відправляють своїм рідним фотографії, поки вони стажуються за кордоном, для юристів у В’єтнамі, котрі у своїх блогах розкривають корупційні махінації», - сказала Г. Клінтон (Marat, 2010). Таким чином, соціальні мережі, які спочатку створювалися як зони віртуального спілкування, у даній ситуації несподівано виступили серйозною альтернативою традиційним ЗМI, які знаходяться під жорстким пресом цензури в окремих країнах. 3 впевненістю можна сказати, що Віртуальна солідарність людей, як нове явище, матиме значне місце в найближчому майбутньому. Як результат, влада різних країн вже звернула свою увагу на цей феномен, i буде докладати зусиль, щоб взяти під свій контроль подібні заклики в соціальних мережах. Як приклад можна назвати введення обмеження на доступ в Інтернет і до соціальних мереж в Білорусії та Китаї (Solovev 2012). Є також низка країн, які чинять тиск на Інтернет - Росія, Бахрейн, Куба, Іран, Північна Корея, Саудівська Аравія, Сирія, Туркменістан, Узбекистан, В’єтнам. Ці данні представлені міжнародною правозахисною організацією «Репортери без кордонів» (Liug, Bondarieva, 2012). 
Однак, попри заборони, Інтернет продовжує виконувати роль комунікативного майданчика, на якому люди висловлюють свої думки та емоції, не побоюючись санкцій з боку політичної влади. Насамперед, це може трохи знизити емоційний запал і віддаляє населення від виразу радикальних форм протесту, хоча при цьому і залишається потужним мобілізаційним каналом рекрутування мас для окремих політичних акторів для організації реальних акцій протесту (Zverev, 2013, р. 96).

Крім того необхідно визнати той факт, що розробка багатомовних доменних імен допоможе усунути мовний бар'єр, який перешкоджає використанню Інтернету неангломовного населення. Тоді використання мов таких країн зробить Інтернет ще більш доступним. Використання Інтернет також залежить від телекомунікаційної інфраструктури. Тому арабські країни повинні використати досягнення в сфері бездротових технологій, особливо для сільських районів. Бездротові технології усунуть географічні бар'єри і витрати, пов'язані з дротяним зв'язком телекомунікаційних систем.

\section{Висновки}

Феномен політичної комунікації в мережі Інтернет поки що недостатньо вивчений, а тому потребує майбутніх досліджень у питаннях взаємозв'язку та взаємовпливу політичного протесту і нових форм медіаактивності. Фактор соціальних мереж в організації протестних рухів повинен вивчатися, зокрема й для забезпечення суспільної та державної безпеки на Арабському Сході, де рівень політичної культури і розвитку суспільної свідомості в більшості країн регіону, дає підстави думати, що, демократія повинна, насамперед, бути підсумком соціально-орієнтованих економічних перетворень, а не випереджати їх. Тому на даному перехідному етапі розвитку арабських країн в суспільстві існує нагальна потреба в ефективному керівництві з боку держави, як за ходом реформ, так і процесом демократизації. Без сильної держави індустріалізуючі арабські країни навряд чи зможуть в нинішніх умовах здійснити економічний прорив і забезпечити поступовий перехід від авторитаризму до демократії, уникнувши при цьому серйозних внутрішніх потрясінь.

\section{References:}

1. Baluev, D. (2012). Rol' novyh SMi v sovremennyh politicheskih processah [The role of the new media in modern political processes]. Nizhniy Novgorod: State University of Nizhny Novgorod.

2. Dogan, M. (1994). Sravnitel'naya politicheskaya sotsiologiya [Comparative Political Sociology].Moscow: Sotsial'no-politicheskii zhurnal.

3. Kyriushko, M. (2010). 'Politychnyi islam - marker kryzovoho suspilstva' [Politicny islam is a marker of crisis]. Ukrainske relihiieznavstvo [Ukrainian relogion Studiues], Spetsvypusk [Special issue], pp. 43-51. 
4. Liug, A., Bondarieva, K. (2012). '«Reportery bez kordoniv» nazvaly vorohiv vilnoho internetu' ["Reporters Without Borders" named the enemies of free internet] Deutsche Welle, [online]. Available at: https://www.dw.com/uk/reporteribez-kordonIv-nazvali-vorogIv-vIlnogo-Internetu/a-15804184 [Accessed $10 \mathrm{March}$ 2019].

5. Lypynskyi, V. (1995). Lysty do brativ-khliborobiv pro ideiu i orhanizatsiiu ukrainskoho monarkhizmu [Letters to brothers-farmers on the idea and organization of the Ukrainian monarchy]. Kyiv: Filidelfiia.

6. Marat, E. (2010). 'Svoboda slova v Internete' [Freedom of speech on the Internet]. Golos Ameriki [Voice of America], [online]. Available at: https://www.golosameriki.ru/a/freedom-internet_2010_01_21-82273292/251245.html [Accessed 10 March 2019].

7. Panjusheva, M. (2012). 'Blogi, mikroblogi i sotsialnyie seti: internetkommunikaci novogo desjatiletija' [Blogs, microblogs and social networks: Internet communications of the new decade]. Media Al'manah [Media Almanac], [online]. Available at: http://mediaalmanah.ru/upload/iblock/462/2011_2_4_panusheva.pdf [Accessed 03 March 2019].

8. Solovev, V. (2012). 'PASE osvobozhdaet internet' [PACE frees internet]. Kommersant', no. 75 [online]. Available at: https://www.kommersant.ru/doc/1923942 [Accessed 03 March 2019].

9. Zverev, A. (2013). 'Rol' Internet-kommunikacii v vyrabotke politicheskih predstavlenij rossijskih grazhdan' [The role of Internet communication in the development of political ideas of Russian citizens]. Vestnik Tomskogo gosudarstvennogo universiteta [Bulletin of Tomsk State University], no. 3 (23), pp. 87-99.

(C) Вербицька Г. А., 2019 